\title{
Max Ferdinand Perutz OM FRS
}

\author{
Alan R. Fersht
}

“'In Science truth always wins' MFP." So reads the inscription on a plaque in the Max Perutz Lecture Theatre in the MRC Laboratory of Molecular Biology, which was unveiled on the afternoon of his funeral. That simple, direct statement sums up Max the scientist and Max the person. Max sought the truth in science and what was right and worthwhile in life. The first half of his life was dedicated to what then seemed the impossible central problem in structural biology - solving the structure of proteins at atomic resolution. The second half saw him blossom further as a scientist, possibly doing his best work after receiving his Nobel Prize; he became an accomplished writer, an ambassador for science and a champion for human rights. He was an inspirational character to scientists and non-scientists alike.

\section{Nobel Prize winning work}

The discovery of X-ray diffraction by wet protein crystals inspired a generation of scientists to look for ways of translating that information to protein structure. However, the interpretation of X-ray diffraction patterns requires knowing not only the intensities and direction of the diffracted rays, which could be directly measured, but also their phases, which remained the stumbling block. The phase problem was unsolved until Perutz, after nearly two decades of effort (punctuated by World War II) introduced the procedure of isomorphous replacement in 1954. It then required some five more years of intense effort to solve the structures of myoglobin, by colleague John Kendrew, and hemoglobin, by Max. It was an accomplishment for which they shared the Nobe Prize in 1962. Soon afterwards, David Phillips and colleagues solved the structure of lysozyme. Then came $\alpha$ chymotrypsin, carboxypeptidase B and ribonuclease $A$, opening the floodgates of three-dimensional protein structures. Had Max stopped being a scientist at that point, his place in history would have been secure as the founding father of one of the most successful and important fields in science and arguably the most important in biology. But, he viewed structure as just the springboard to understanding function.

\section{From structure to function}

Knowing the three-dimensional structure of proteins impacted on crystallographers and biochemists in strikingly different ways. Sadly, some of the traditional enzymologists turned their backs on the

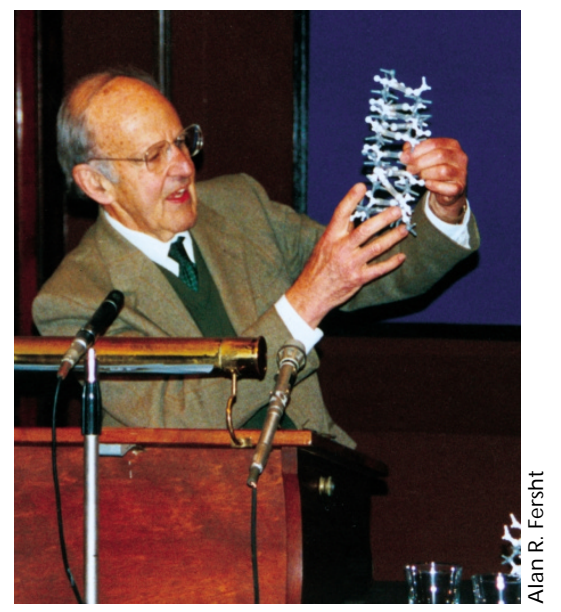

$1914-2002$

new information until it was impossible to ignore and others turned to systems that they thought were beyond the reach of protein crystallography. But at the same time, a young generation of scientists flooded into the protein crystallography field, and a not insignificant number have made pre-Christmas trips to Stockholm. Some very bright young protein scientists were inspired to devise new methods and experiments to exploit the new structural information. Many crystallographers honed their skills to produce a large series of structures and far more complex ones. Meanwhile, Max set about solving the allosteric mechanism of hemoglobin for with his unerring insight, he had chosen a protein that was ideal for bridging the gap between structure and function before the widespread use of present day protein engineering techniques - it was the cracking of crystals of deoxyhemoglobin on oxygenation that had first attracted him toward this protein.

It was at this stage, the second part of his career, that I got to know Max personally. I joined the MRC in 1969 and shared a tiny laboratory with him. Max would come into the lab at 9:30 each morning, having finished his admin- istration for the day, and proceed to perform ingenious biophysical experiments. His former research student would lecture Max (as if he were the student!) on how to do experiments. His humility, warmth and engaging eccentricities - we have fond memories of Max warming bananas in the $37^{\circ} \mathrm{C}$ oven during those less safety conscious days - his obvious enthusiasm and quick intelligence made it easy for him to collaborate with others. $\mathrm{He}$ rapidly embraced new techniques, such as NMR and other new methods of increasing sophistication. He became the first molecular pathologist, analyzing the effects of natural mutations on the oxygen affinity of hemoglobin and related pathologies, including sickle cell anemia. By analyzing the large number of natural hemoglobin mutants isolated from patients, analyzing hemoglobins from other species and altering specific amino acid residues by protein chemistry and eventually protein engineering, Max was able to solve the mechanisms of the Bohr effect and the allosteric transition of hemoglobin. This was his second great triumph, using structure as the starting point for functional analysis of a protein.

\section{The latter years: Huntington's disease}

Max's final research project, and his consuming passion in his last years, was the role of polyglutamine repeats in Huntington's disease. He first postulated a 'polar zipper' model, and in his last six months interpreted diffraction data to give a general model for amyloid structure. Two papers describing these results, entitled "Aggregation of proteins with expanded glutamine and alanine repeats, of the glutamine-rich and asparagine-rich domains of Sup35, and of the amyloid $\beta$-peptide of amyloid plaques" and "Amyloid fibers are water-filled nanotubes" are now in press in Proc. Natl. Acad. Sci. USA. These papers were finished just ten minutes before Max was admitted to Addenbrookes' Hospital for emergency surgery. He had delayed admission from that morning to the afternoon. Max was elated to have ended his career on a high point. 


\section{Max the teacher, the w riter and the person}

Max taught by example, communicating to his audiences with clarity and infectious enthusiasm, and by directly encouraging and helping young scientists. He taught many of us how to write and always found time to read our papers and correct them with his unmistakable scrawl. Early versions would come back covered in red ink, with pointers on how to write clearly and questions about the science and the presentation. After a few such lessons, the return of an unmarked manuscript showed that one had graduated in the art of communicating scientific achievements.

Max was a prolific writer, producing some 42 articles, reviews and comments for the New York Review of Books between 1981 and 2001. These vary from his reviews of books, especially biographies of scientists, defense of contraception and other more general articles. It is these writings that perhaps best reveal many aspects of his character and interests. As an example, I refer you to his review of Five days in London, May 1940 by John Lukacs (Yale University Press; 2001), which detailed the crucial days in which Churchill persuaded the British Cabinet not to acquiesce to Hitler but instead to begin the battle that would eventually save western civilization. Exiled from Austria for being a Jew, Max was intensely upset at being interned and deported from Britain at the beginning of World War II for being an Austrian. It was Churchill who had demanded "Collar the lot", and 7,500 internees and aliens of German, Austrian or Italian origin were selected for shipping to Canada and Australia in mid 1940 despite many of them being of Jewish extraction. Whereas others would hold this against Churchill, Max, who had suffered directly from these events, held Churchill in the highest regard. This review, in which Max warmly appreciated Churchill, thus illuminates a central element of Max's character: he saw the good in all people objectively, without holding grudges and with unswerving loyalty to his friends.

Max's flair for writing was a late development. Leo Perutz, the distinguished writer and a relative, once told Max when he was a boy that he would never be a writer, and so one of his most cherished awards was one for scientific writing. "I wish I had made you angry earlier" (Cold Spring Harbor Laboratory Press; 1998) contains a marvelous selection of his essays on science, scientists and humanity. Although mild and kindly by nature, he would defend attacks on his science or scientists like a mother bear defending her cubs. He would not flinch from defending scientists whose human rights were threatened.

\section{The legacy of Max Perutz}

Max is really the father to us all in structural biology: he solved a protein structure, analyzed it to understand its functional mechanism at atomic detail, looked at the role of mutations in disease and thought about drug design. And he did it first! The character of a scientist is often transmitted though the generations. One can learn a lot about a scientist from the behavior of his students and his students' students. Protein crystallography is one of the least fractious and most supportive branches of science, which is a not insignificant factor in its success. Structural biology and its students are Max's lasting legacy. He knew his legacy and so died a happy and fulfilled man, surrounded by his family and a constant stream of old friends who came to his bedside to pay their last respects and whom he thanked personally for their friendship. He is survived by a devoted family whose support was an integral part of his success.

Alan R. Fersht is at the MRC Centre for Protein Engineering, MRC Centre, Cambridge CB2 2QH, UK. email:arf25@ cam.ac.uk. 